\title{
Ultrastructure of malpighian and inflammatory cells in epidermal papillomas of white suckers Catostomus commersoni
}

\author{
I. R. Smith*, K. W. Baker, M. A. Hayes, H. W. Ferguson \\ Fish Pathology Laboratory, Department of Pathology, Ontario Veterinary College, University of Guelph, Guelph, Ontario, \\ Canada N1G 2W1
}

\begin{abstract}
Epidermal papillomas affect many white suckers Catostomus commersoni in the Great Lakes of North America, in particular among populations inhabiting polluted environments. Representative papillomas were examined ultrastructurally for viruses, inflammatory cell infiltrates and malpighian cell morphology. Three distinctive gross morphologies of papillomas all contained malpighian cell hyperplasia with some papilloma formation. Lip papillomas had normal malpighian cells but intercellular spaces were enlarged, desmosomes were aggregated, and increased numbers of all leukocytes, but particularly neutrophils, were evident. Discrete papillomas on the body surface contained normal malpighian cells with no aggregation of desmosomes, but enlarged intercellular spaces were filled with granular debris and a prominent neutrophil infiltrate was common. Diffuse papillomas (plaques) on the body surface contained malipighian cells with aggregated desmosomes. Lymphocytes and neutrophils were extremely abundant. Abnormal desmosome aggregations could alter the growth characteristics of malpighian cells making up lip papillomas and plaques. Inflammatory and immunologic cell infiltrates observed in these papillomas could limit the growth or persistence of these neoplasms. No virus-like inclusions were identified in any preparations. The role of viruses in the epidermal papillomas affecting white suckers in polluted locations of the Great Lakes remains unresolved.
\end{abstract}

\section{INTRODUCTION}

Chemical carcinogens in sediments have been widely implicated in the induction of both skin and liver neoplasms in bottom-fish inhabiting polluted locations (Smith et al. 1979, Baumann et al. 1982, Black 1984. Malins et al. 1985, Smith et al. in press). Skin neoplasms (epidermal papillomas) affecting fish in unpolluted environments often contain virus particles (Carlisle 1977, Jenson \& Bloch 1980, Pilcher \& Fryer 1980, Kelly et al. 1983, Yamamoto et al. 1983, 1985 McAllister et al. 1985, Bloch et al. 1986), and virus treatment alone can induce similar lesions (Kimura et al. 1981). Epidermal papillomas affect brown bullheads Ictalurus nebulosus and white suckers Catostomus commersoni in unpolluted but particularly in polluted areas of the Great Lakes of North America; these papillomas are similar in structure to the papillomas contain-

\footnotetext{
- Present address: Biohazards Laboratory, Aquatic Biology Section, Water Resources Branch, Ontario Ministry of the Environment, PO Box 213, Rexdale, Ontario, Canada M9W 5L1
}

ing virus particles in other species (Smith \& Ferguson 1985, Smith \& Zajdlik 1987, Smith et al. in press). Papillomas affecting white suckers are reported to contain C-type virus particles and reverse-transcriptase (Sonstegard 1977), but this observation is not well supported. White suckers kept in laboratory tanks for 3 mo after spawning developed new papillomas in the apparent absence of pollution (Smith \& Zajdlik 1987) suggesting viruses or other unknown factors are capable of causing these neoplasms. Chemical treatment of the epidermis of brown bullheads, which has induced similar papillomas, suggests that the carcinogenicity of environmental chemicals is a possible mechanism for papilloma induction in white suckers, possibly by activating latent viruses (Black 1982). Epidermal papillomas also may develop more often in polluted areas because of increased viral infection rates due to higher fish densities, skin abrasion, depression of the immune system, or chemicals and viruses acting as co-carcinogens.

Another possible mechanism for unusually high papilloma incidences may be abnormal persistance of 
viral lesions. Papilloma regression has been identified in a variety of aquatic species including white suckers (Smith \& Zajdlik 1987), regression possibly following virus transmission or inactivation. Resolution may be accompanied by inflammatory infiltrates (Carlisle \& Roberts 1977, Peters \& Peters 1977, 1979, Pfeiffer et al. 1979, Asashima et al. 1982, 1985, Smith \& Zajdlik 1987), or regression may be primarily immune-mediated (Carlisle \& Roberts 1977). The immune response of fish to other antigens besides bacteria, and the effects of chemicals on cellular immunity, are not well studied (Roberts 1978, Walczak 1985), but it is known that fish leucocytes posses in vitro 'killer' cell activity (Evans et al. 1984, Moody et al. 1985, Cleland \& Sonstegard 1987). The types of cells involved in in vivo immune responses to neoplastic growths such as papillomas are generally unknown but the epidermis can mount a distinct immunologic response (St. Lovis-Cormier et al. 1984, Peleteiro \& Richards 1985, Lobb 1987). The regression of papillomas on white suckers observed after spawning (Smith \& Zajdlik 1987) provides an opportunity to identify the relative abundance of inflammatory and immunologic leucocytes, as well as the structure of the affected malpighian cells and the presence of viruses. Leucocytic infiltration observed in these epidermal papillomas suggests that immune-suppression is an unlikely mechanism for elevated neoplasm incidences, but that immune-mediated regression is possible. A viral etiology was not confirmed.

\section{MATERIALS AND METHODS}

Fish acquisition. Mature white suckers were captured with seine nets from 2 small streams on the north shore of Lake Ontario during their spawning migrations into these rivers. Suckers spawning in Grindstone Creek, Burlington, Ontario, and Oakville Creek, Milton, Ontario were selected because these populations have the highest prevalences of epidermal papilloma in the Great Lakes. Specimens were kept in laboratory holding tanks with $12^{\circ} \mathrm{C}$ running well water, and autopsies were carried out between 2 and 4 wk after capture. Suckers were briefly anaesthesetized and then killed with a blow to the head to reduce damage to the skin during autopsy.

Tissue preparation. Tissues samples 3 to $5 \mathrm{~mm}$ in diameter were excised and immediately immersed in cold $\left(4^{\circ} \mathrm{C}\right) 2.5 \%$ glutaraldehyde in $0.1 \mathrm{M}$ phosphate buffer at $\mathrm{pH} 7.4$. Tissues were stored for up to 6 mo at $4{ }^{\circ} \mathrm{C}$ prior to secondary processing. Glutaraldehydefixed tissues were cut into smaller pieces, ca $2 \mathrm{~mm}^{2}$, and subsequently fixed with $1 \% \mathrm{OsO}_{4}$ in $\mathrm{K}_{2} \mathrm{Cr}_{2} \mathrm{O}_{7}$ buffer (Dalton's fix). Samples from the scaled body surface were oriented and sectioned at right angles to the scales. Lip samples were also oriented and sectioned for cross-sectional examination. All samples were fixed with $\mathrm{OsO}_{4}$ for 2 h at $4{ }^{\circ} \mathrm{C}$, rinsed with 2 changes of $50 \%$ acetone, dehydrated through a graded series of acetones, infiltrated with epon-araldite, polymerized, and sectioned with a Reichert ultra-microtome. Thin sections, ca $110 \mathrm{~nm}$ thick, were stained with uranyl acetate and lead citrate and examined using either a Hitachi or JEOL transmission electron microscope. Thick sections (1 $\mu \mathrm{m}$ ) were stained with Toluidine Blue $O$ and examined by light microscopy. Selected formalin-fixed $(10 \%)$ samples were de-embedded from paraffin, cleared with acetone and re-embedded in epon-araldite as described above.

Eleven samples of white sucker lip, including 8 lip papillomas and 3 controls (grossly normal), were morphologically characterized using light and electron microscopy. Thirteen samples of body epidermis were examined, including 2 controls and 11 grossly identifiable ( 6 focal, 5 diffuse) lesions. Seventeen additional lip papillomas, previously fixed and stored in glutaraldehyde, were homogenized, sedimented, and examined for the presence of virus particles. Tissues were minced in 3 to $4 \mathrm{ml}$ PBS $(0.1 \mathrm{M}, \mathrm{pH} 7.3)$ with a razor blade and then homogenized until a milky-white solution could be decanted from the coarse, particulate debris. After preliminary centrifugation at $2000 \mathrm{rpm}$ for $10 \mathrm{~min}$, the supernatant was further spun at $50000 \times \mathrm{g}$, $4{ }^{\circ} \mathrm{C}$, for $2 \mathrm{~h}$. Drops of the supernatant solution were placed on formvar-coated grids for 30 or $60 \mathrm{~s}$. After gently blotting excess solution, the grids were then stained with $2.5 \%$ phosphotungstic acid, $\mathrm{pH} 6.5$, for 30 or $60 \mathrm{~s}$. Grids were then examined for viral particles

\section{RESULTS}

\section{Normal lip}

An epidermal layer of varying thickness overlies the loose dermal tissue of the lip (Fig. 1A). Epidermal malpighian cells were uniform in shape and volume and only in the outermost 2 or 3 layers did they undergo some limited flattening. Occasional mitotic figures were present at all levels in the epidermis. Teardrop-shaped 'chemoreceptors', which were very well innervated, were often associated with localized thinning of the epidermis. Chemoreceptors were comprised of morphologically distinct cell aggregates; the apex of each structure extended to the epidermal surface (Fig. 1A, B). Regularly distributed infiltrating cells were concentrated in basal and suprabasal locations and to a lesser extent within the more external layers.

Electron microscopy of normal lip epithelium revealed the suprabasal malpighian cells to be 

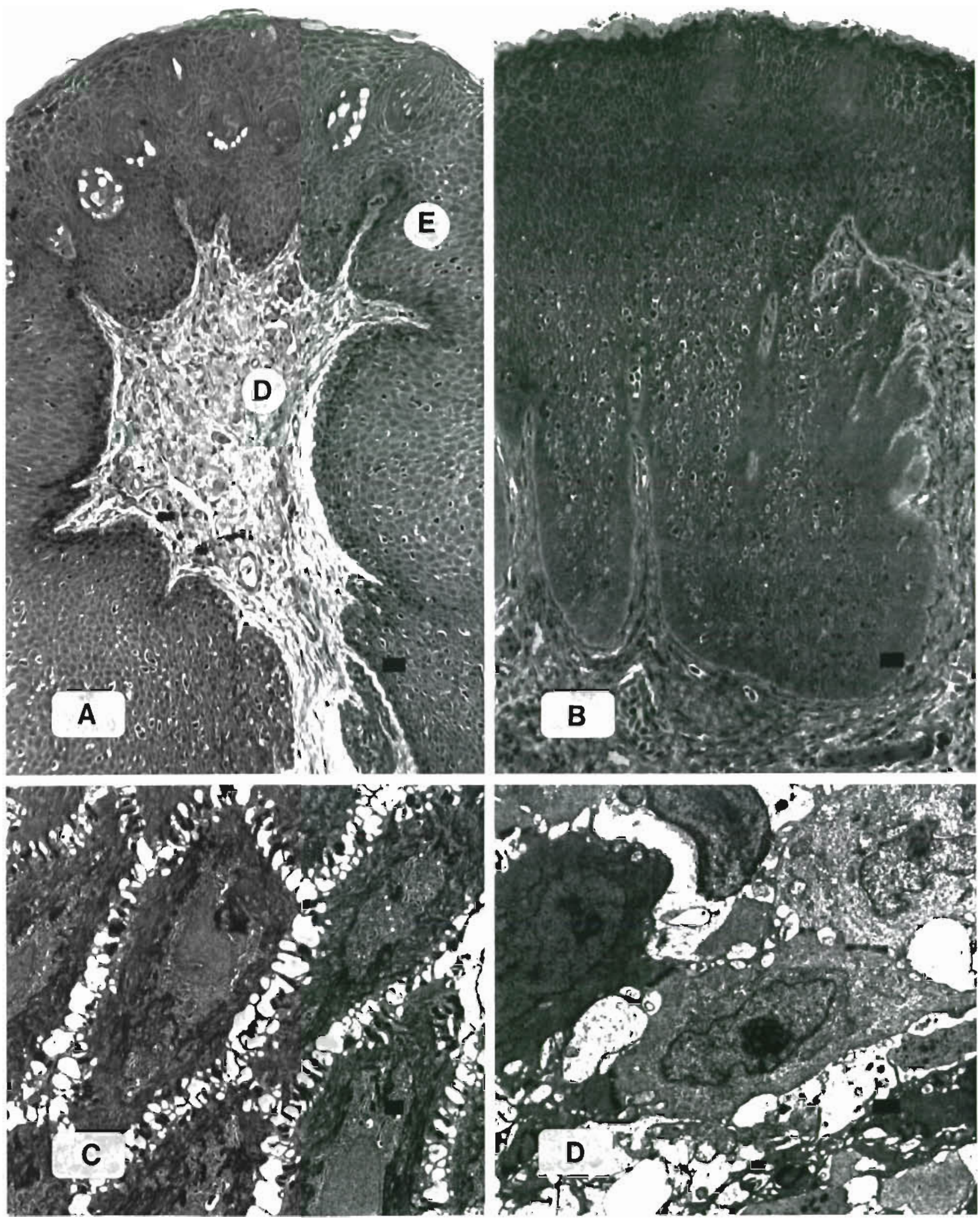

Fig. 1. Catastomus commersoni. Light and electron micrographs of white sucker lip. (A) Normal lip epithelium (E) and dermis (D) Note the intraepidermal chemoreceptors and regular distribution of basal, infiltrating leucocytes. Bar $=25 \mu \mathrm{m}$. (B) Lip papilloma with characteristic epidermal hyperplasia and abnormal dermal papillae. Bar $=25 \mu \mathrm{m}$. (C) Malpighian cells as seen both in normal lip and in the suprabasal layers of many lip papillomas. Bar $=1 \mu \mathrm{m}$. (D) Malpighian cells in superficial layers of a lip papilloma. Note the abnormal intercellular spaces and aggregate desmosomes. Bar $=1 \mu \mathrm{m}$ 
uniformly cuboidal in shape with tonofilaments and free ribosomes occupying much of the available cytoplasm (Fig, 1C). Tonofilaments usually surrounded a central zone consisting of the nucleus, numerous mitochondria, rough endoplasmic reticulum and Golgi apparatus. Desmosomes and associated tonofilaments were evenly distributed around the cell periphery, often occupying the terminus of short, slender extensions of the plasma membrane. Malpighian cells were usually separated by a moderately large intercellular space, but the outermost 2 or 3 cell layers possessed tighter cell-cell associations. Basal malpighian cells were columnar, possessing an interdigitating basal profile, and resting upon a continuous basal lamina of uniform thickness.

Infiltrating cells were most abundant among basal and suprabasal cell layers and less so towards the epidermal surface (as observed by light microscopy): most cells resembling lymphocytes (Ferguson 1976, Peleteiro \& Richards 1985).

\section{Lip abnormalities}

Lip abnormalities contained a thickened hyperplastic to papillomatous epidermis over a normal dermis (Fig. 1B). Constituent malpighian cells were uniform in size and differentiative character, throughout thickened areas of each lesion. Mitotic figures were relatively common. Cellular infiltrates were notably heavier than in normal tissues. Chemoreceptors were less evident in areas of extreme hyperplasia.

Malpighian cells appeared ultrastructurally normal as previously described, being roughly cuboidal in shape, with a normal complement and distribution of cytoplasmic organelles. Tonofilaments occupied the peripheral cytoplasm while the sometimes-lobed nucleus, mitochondria, rough endoplasmic reticulum, and Golgi apparatus occupied the central area of the cell as in normal malpighian cells. Intercellular spaces were moderately enlarged throughout most of the lesion but resembled controls in basal and suprabasal areas. These spaces were most enlarged in the outermost cell layers (unlike controls) where they were often filled with granular and cellular debris (Fig. 1D). Slender villous projections of the malphigian cells surface were associated with larger intercellular spaces. The structure and distribution of desmosomes was often different within a single lesion, usually accompanying the variation in the size and character of the intercellular space particularly in outer layers. Desmosomes in the outermost layers were usually aggregated and restricted to a limited area on the keratinocyte surface (Fig. 1D), in contrast to the regular distribution observed in controls and the basal and suprabasal layers of abnormalities; internalized desmosomes were common.

Malpighian cells in some papillomas contained free cytoplasmic aggregates of glycogen-like dense particles measuring ca $29 \mathrm{~nm}$ in diameter (Fig. 2A). Cytoplasmic aggregates were observed within both suprabasal and superficial malpighian cells, and within intra-epidermal macrophages.

Infiltrating cells were unusually abundant throughout the epidermis in most lip papillomas, particularly in the basal and suprabasal cell layers where they often formed small aggregates. Leucocytes were phagocytically active, and often contained dense, cell-derived inclusion bodies, unlike leucocytes in normal lip. Lymphocytes were present in numbers similar to normal. lip and morphologically resembled those in normal lip, possessing a single, sometimes clefted nucleus with central and peripheral zones of dense chromatin (Fig. 2B, C). The cytoplasm of lymphocytes was relatively featureless and contained limited numbers of small mitochondria, varying amounts of rough endoplasmic reticulum and an abundance of free ribosomes. Neutrophils comprised the greater portion of the increased cellular infiltrate. Such cells had an irregularly-shaped nucleus, sometimes clefted or lobed, with both central and peripheral areas of densely-stained (condensed) chromatin (Fig, 2B, C). Neutrophils also differed from the lymphocytes in having a larger cytoplasmic volume and complement of cytoplasmic organelles, including a sometimes prominent rough endoplasmic reticulum, an active Golgi apparatus, primary and secondary lysosomes, an abundance of small vacuoles and variable numbers of granules (Fig. $2 \mathrm{~B}$ vs $2 \mathrm{C}$ ). Macrophages were the least prominent of infiltrating leucocytes. These cells were similar to the neutrophils described earlier, except for a non-lobed nucleus with densely-stained, clumped nuclear chromatin and few or no cytoplasmic granules (Fig. 2D).

Virus particles were not identified in any of the preparations examined by transmission electron microscopy, including post-mitochondrial fractions of homogenates from lip papillomas.

\section{Normal body skin}

Normal body epidermis is an even 10 to 25 cell-thick layer of malpighian cells resting on an even basal lamina, with some epidermis surrounding scales. Mucous and club cells are relatively common, sensory structures being present only in the area of the lateral line. Epidermal leucocytes are uncommon, normally being restricted to the suprabasal layer. Ultrastructurally, epidermal cells were similar to those previously described in the lip 

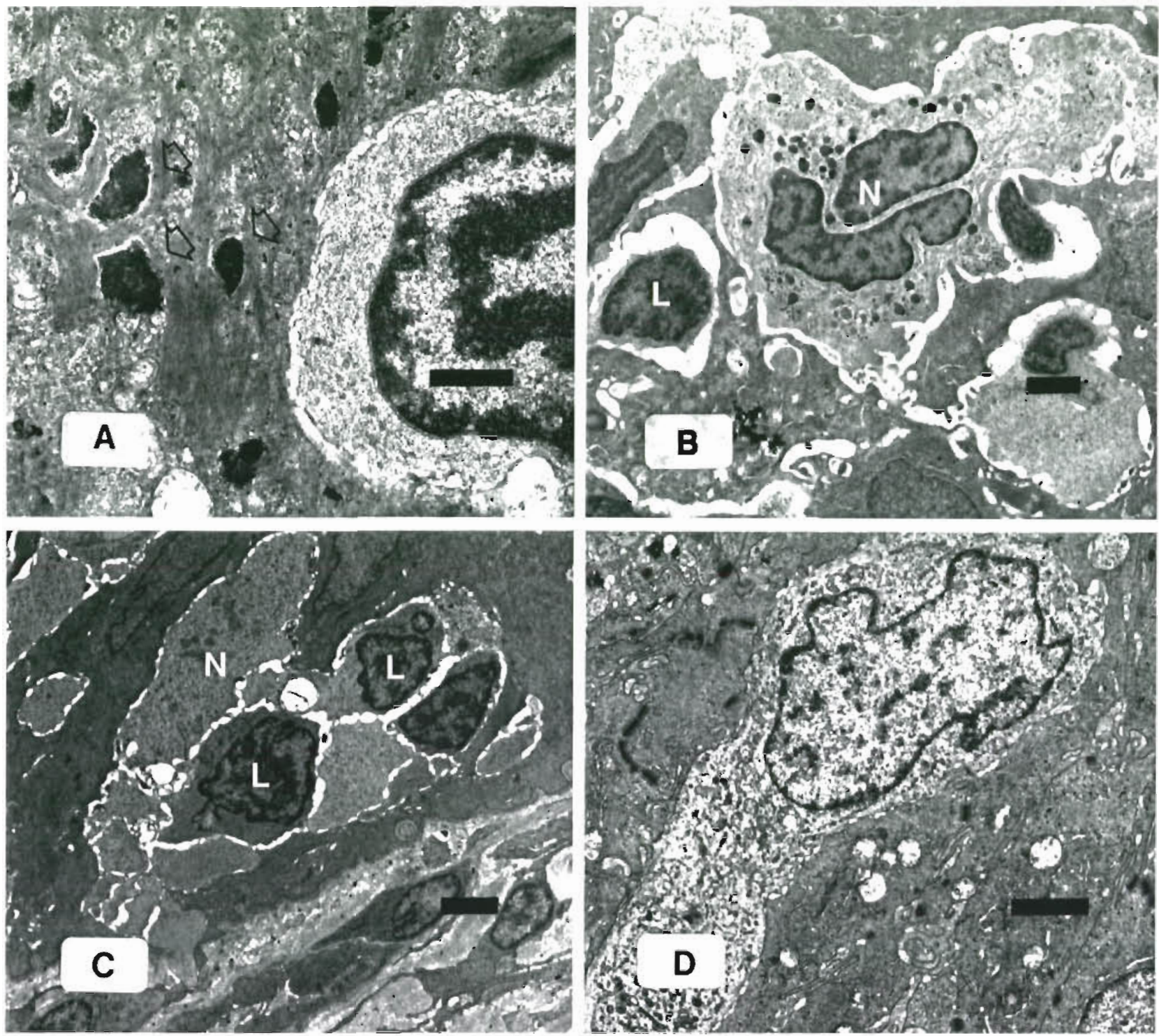

Fig. 2. Catastomus commersoni. Electron micrographs of lup papllomas Bars = $1 \mu \mathrm{m}$ (A) Glycogen-like aggregates (arrows) in suprabasal malpighian cells. Individual granules measure $29 \mathrm{~nm}$ in diameter (B, C) Inflammatory cells occurring in lip papillomas Lymphocytes (L) and neutrophils (N) with charactenstic nuclear and cytoplasmic morphology Note the absence of neutrophil granules in (C), a common finding in some papillomas. (D) Large macrophage with few or no granules

\section{Skin abnormalities}

Two grossly different proliferative skin lesıons were observed on the bodies and fins of white suckers. These were discrete raised foci, termed papillomas, of marked epidermal hyperplasia with frequent downgrowth of epidermal pegs (Fig. 3A), and more diffuse low focl, termed plaques, of mild to moderate hyperplasıa, moderate to marked spongiosis, an extensive chronic-actıve inflammatory component and less frequent downgrowth of epidermal pegs (Fig. 3B). Papillomas contanned a limited but regular distribution of infultrating leucocytes whereas plaques featured numerous irregularly distributed leucocytes (Fig. 3C, D). Mucous and fright cells were conspicuously absent from both abnormalities.

\section{Papiliomas}

Malpighian cells forming most of the papillomas were similar in morphology and differentiative character, being roughly cuboidal. Malpighian cells on the epidermal surface were moderately flattened and partıally degenerate. Basal cells were columnar 

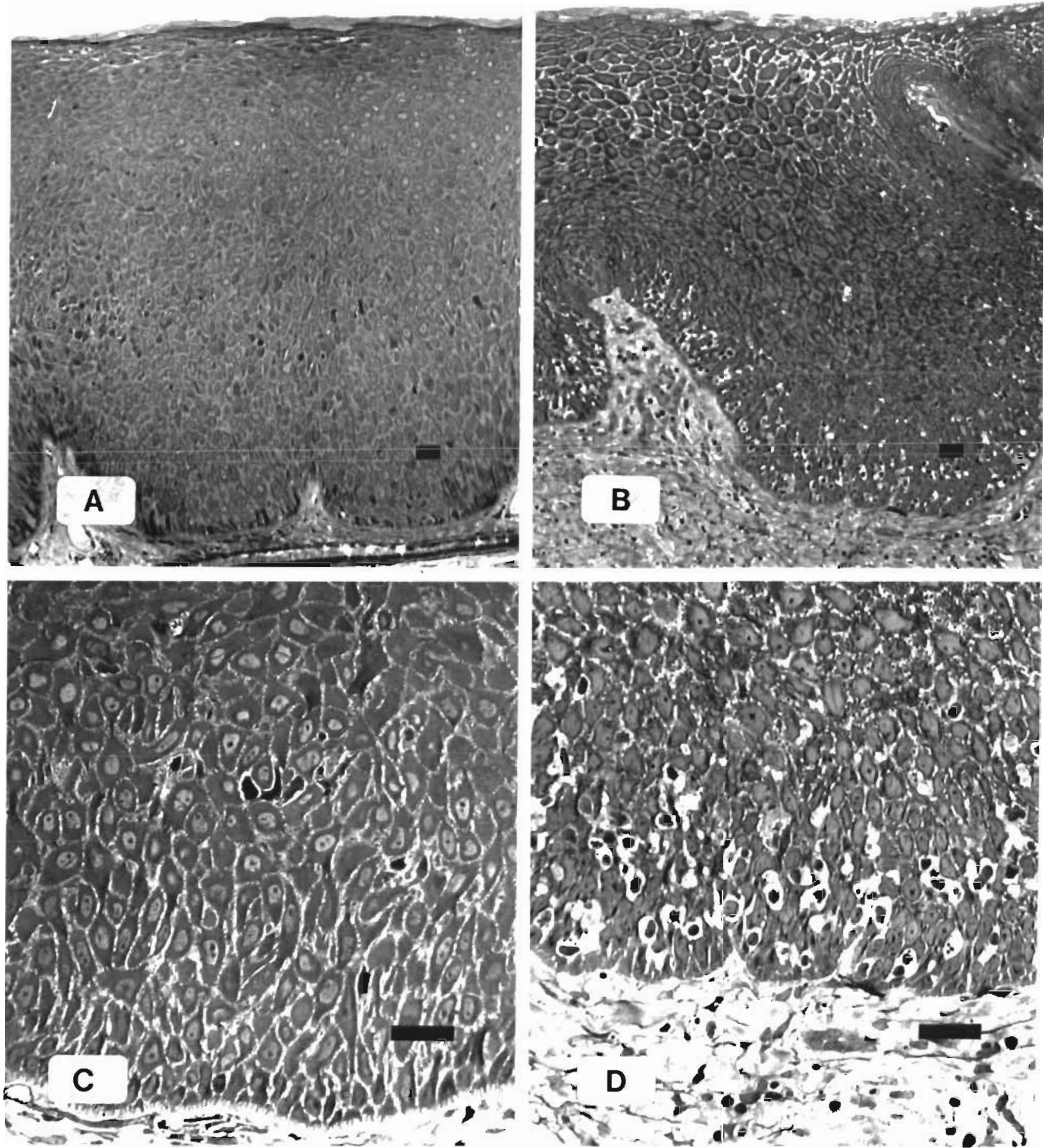

Fig. 3. Catastomus commersoni. Light micrographs of papillomas and plaques on the skin of white suckers. Bars $=25 \mu m$. (A) A papilloma with formation of medium-sized papillae. (B) A plaque with papillae similar to those occurring in papillomas. (C) Basal Iayers of a papilloma showing an even distribution of similarily-shaped, moderately-differentiated suprabasal malpighian cells. (D) Basal layers of a plaque featuring marked necrosis and leucocyte infiltration

in shape and the epidermal-dermal interface was highly irregular in profile. Hemidesmosomes were regularly distributed on the basal cell plasma membranes, which in turn were closely apposed to an uninterrupted, basal lamina of uniform thickness and density. Each malpighian cell possessed a large cytoplasmic volume containing large numbers of free ribosomes, peripheral aggregates of tonofilaments 
and tonofibrils, and perinuclear distributions of mitochondria, rough endoplasmic reticulum, and Golgi apparatus. Intercellular spaces were moderately enlarged, and were often filled with fine, granular material which was prominent in the upper layers. Desmosomes were evenly distributed, not aggregated, usually appearing at the terminus of slender elongations of the cell surface (Fig. 4A). Internalized desmosomes were common.

Leucocytes infiltrating the epidermis were mostly neutrophils with an ovoid or clefted nucleus and a large cytoplasmic volume. Their cytoplasm contained many dense granules of varying dimensions, a welldeveloped Golgi apparatus, an even distribution of free ribosomes, and a prominent rough endoplasmic reticulum. Lymphocytes, identified by their limited featureless cytoplasm and more densely stained nucleus, were only sparsely distributed throughout the lesion. Macrophages were uncommon. Virus particles were not observed in any papillomas.
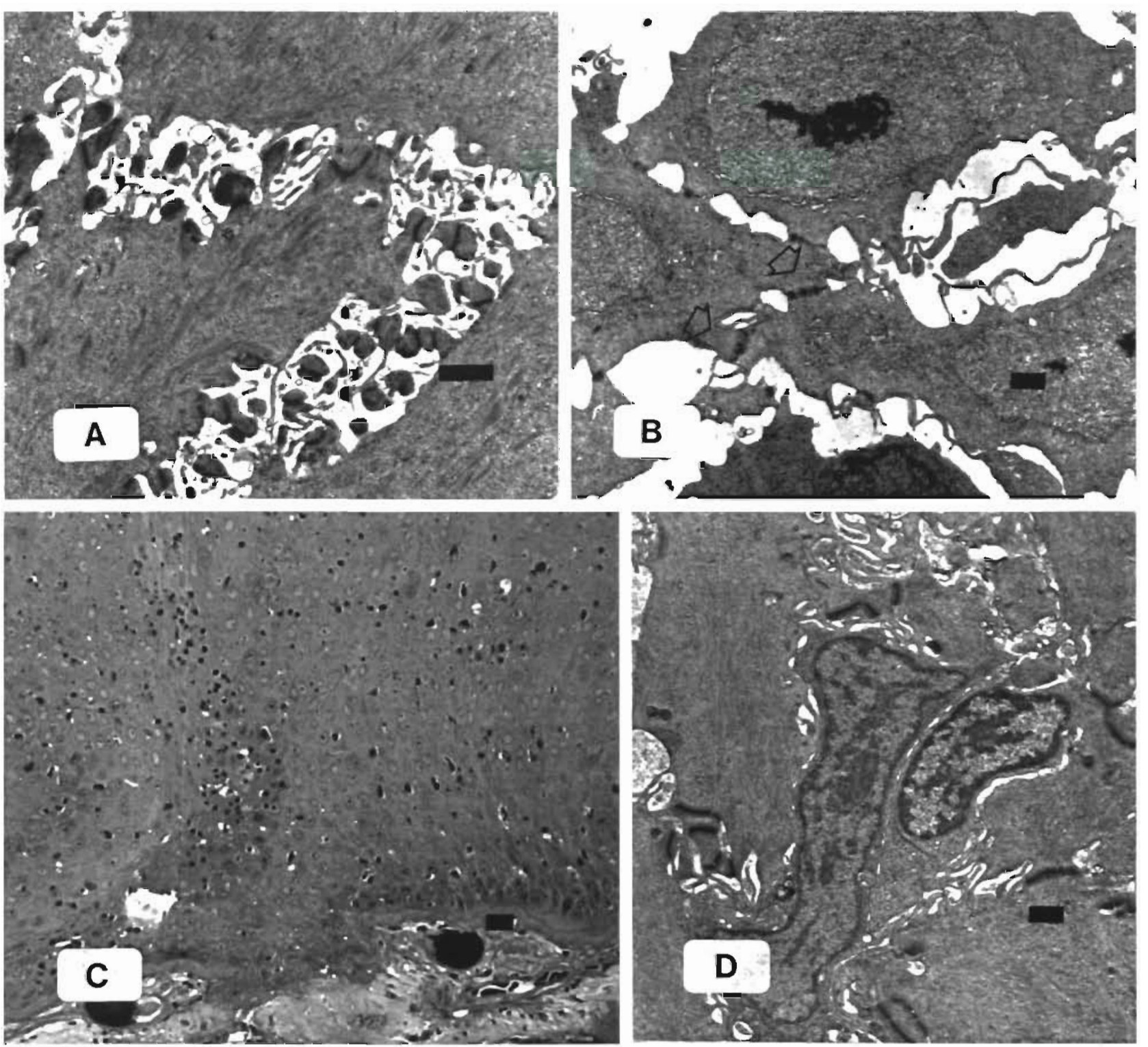

Fig. 4. Catastomus commersoni. Light and electron micrographs of white sucker body papillomas and plaques. (A) Malpighian cells in body papillomas separated by large intercellular spaces which included abundant and regularly distributed desmosomes. Bar $=1 \mu \mathrm{m}$. (B) Malpighian cells in a plaque separated by large intercellular spaces and aggregate desmosomes (arrows). Bar $=$ $1 \mu \mathrm{m}$. (C) Light micrograph of the basal region of an invasive plaque penetrating basal lamina and underlying dermis. $\mathrm{Bar}=25 \mu \mathrm{m}$. (D) Infiltrating cells with indistinct morphology, either degranulated granulocyte or monocyte. Note the aggregate desmosomes on the surface of adjoining malpighian cells. Bar $=1 \mu \mathrm{m}$ 


\section{Plaques}

Malpighian cells in plaques had variable staining densities but were otherwise uniform in their structural appearance. Nuclei were polymorphic or lobed, often containing central dense convoluted nucleoli. Cytoplasmic organelles, Golgi apparatus, rough endoplasmic reticulum, and mitochondria were perinuclear in distribution. Tonofilaments and tonofibrils were loosely arranged and occupied a large part of the peripheral cytoplasm. Malpighian cells in plaques expressed shorter, less elaborate membrane processes than those observed in discrete foci. Desmosomes were an aggregate type, often formed into linear arrays of individual desmosomes (Fig. 4B) or into single long desmosomes. Cells on the surface of plaques were flattened, retaining a large complement of cytoplasmic organelles. Basal cells were columnar with an even distribution of ventrally-placed hemidesmosomes resting upon a continuous basal lamina of uniform thickness, which was interdigitating in profile. Intercellular spaces were enlarged throughout the epidermis, especially in areas of heavy leucocyte infiltration.

Infiltrating cells were more numerous and less regularly distributed in plaques than in papillomas, being concentrated in basal and suprabasal locations. The evolution of aggregated desmosomes paralleled an increased prevalence of inflammatory cells. Infiltrating leucocytes were predominately neutrophils and lymphocytes. Macrophages were present in much smaller numbers, being attracted to areas of single cell necrosis, associated with the appearance of large cytoplasmic inclusion bodies; such cells frequently contained recognizable fragments of cell debris. Virus particles were not observed in any of the plaques examined.

A single invasive plaque with a marked inflammatory character was examined after paraffin de-embedment (Fig. 4C). Malpighian cells were very tightly associated with infiltrating leucocytes being evenly distributed. Invasion of malpighian cells into the dermis was not observed with the electron microscope though a somewhat irregular basal lamina was visible. Desmosomes were predominately the 'aggregate' type, but without accompanying enlargement of the intercellular space (Fig, 4D) as seen in most plaques. Malpighian cells exhibiting a rarefied overall appearance with a dense, fragmented, sometimes blebbing nucleus were sporadically distributed. Single cell necrosis was also common. No virus particles were observed.

\section{DISCUSSION}

Focal plaques and papillomas on white suckers consistently featured hyperplasia of normal epidermal mal- pighian cells, except for variable nuclear morphology, intercellular spacing and desmosome structure. Desmosomes were evenly distributed in malpighian cells of normal skin and body papillomas, whereas lip papillomas and particularly plaques had cells with aggregate desmosomes. Macrophage numbers were similar in normal and proliferative epidermis, but lymphocytes were increased in plaques and neutrophils were more abundant than normal in all abnormalities. No virus particles were identified in any lesions.

Epidermal papillomas described in many species contain a thickened epidermis over either a flat or folded (papillae) basal lamina (Winquist et al. 1968, Carlisle \& Roberts 1977, Peters \& Peters 1977, 1979, Roberts \& Bullock 1979, Bylund et al. 1980, Yamamoto et al. 1983, 1985, Bloch et al. 1986). The descriptive term 'epidermal papilloma', by its common use, obviously includes lesions which are either hyperplastic or papillomatous histologically, this latter distinction being based on the appearance of the dermal/epidermal papillae. Papillomas of white suckers regardless of gross morphology or anatomic location feature a continuum from flat to papillae as described elsewhere and there is no evidence for plaques developing into papillomas (Smith \& Ferguson 1985, Smith \& Zajdlik 1987, Smith et al. in press). In white suckers and walleye Stizostedion vitreum, 2 grossly distinctive (body) but histologically similar skin papillomas are recognized (Kelly et al. 1983, Smith \& Ferguson 1985, Yamamoto et al. 1985, Smith et al. in press). Lip papillomas affecting white suckers resemble those of eels Anguilla anguilla in Europe and brown bullheads Ictalurus nebulosus, the latter in areas of the Great Lakes from which the white suckers for this study originated (Peters \& Peters 1977, 1979, Smith \& Ferguson 1985, Smith et al. in press). Epidermal papillomas in all species contain moderately differentiated malpighian cells from the suprabasal region with abnormal nuclear morphology, increased intercellular spacing and elongate cytoplasmic processes (Winquist et al. 1968, Peters \& Peters 1979, Yamamoto et al. 1983, 1985, Bloch et al. 1986). Suprabasal malpighian cells are normally mitotic in fish epithelium (Kranz et al. 1980) and thus are a likely site for hyperplastic or neoplastic growths to originate. Reductions and abnormalities of cell-cell junctions, such as desmosomes in epidermal tissue, are fairly typical in neoplasms (Henderson \& Papadimitriou 1982, Ghadially 1985), and have been described in eel papillomas (Peters \& Peters 1977). The aggregate desmosomes in plaques and lip papillomas on white suckers are unlike the normal distribution in normal skin and in body papillomas but abnormal desmosomes do not strictly correlate with observed frequencies of regression of each lesion type (Smith \& Zajdlik 1987). Morphological differences between lesions could however result from differences in cell-cell 
contact. Body papillomas with normal desmosomes may be focal accumulations of cells which exfoliate slowly, whereas plaques and lip papillomas may accumulate cells which exfoliate more quickly, possibly because of or resulting in abnormal desmosome structure

Lymphocytes were the most common leucocyte in the normal epidermis of white suckers and were observed in similar numbers in lip and body papillomas, likely representing the normal immune-surveillance hypothesized in other species (St. Louis-Cormier et al. 1984, Peleteiro \& Richards 1985, Lobb 1987). Increased numbers of lymphocytes in plaques suggests a cellular immune response to some antigenic component in these lesions. The structure of lymphocytes in both normal and hyperplastic epidermis was typical of fish lymphocytes (Ferguson 1976, Peleteiro \& Richards 1985, Parish et al. 1986, Roubal 1986), and their presence might indicate antigenic or cytocidal activity as observed towards mammalian and fish tumor cells in vitro (Evans et al. 1984, Moody et al. 1985, Cleland \& Sonstegard 1987). While in vivo activity of lymphocytes towards fish tumor cells has not been clearly demonstrated lymphocytes do infiltrate salmon papillomas which slough off (Carlisle \& Roberts 1977). Hyperplasia in lip and body papillomas didn't attract lymphocytes, however hyperplasia can apparently be associated with increased numbers of neutrophils or macrophages (Phromsuthirak 1977). Neutrophils unusually abundant in all 3 types of papillomas possessed typical cytoplasmic organelles such as lysosomes, vacuoles and dense granules (Parish et al. 1986, Roubal 1986), but cells resembling the eosinophilic granular cell widely reported in white suckers and other species (Roberts et al. 1971, Barber \& Westerman 1975, Lester \& Daniels 1976, Roubal 1986) were not observed. Macrophages were much less prominent. Neutrophils and macrophages accompanied the sloughing of salmon papillomas (Carlisle 1977, Carlisle \& Roberts 1977) and were a component of inflammation in wounded areas (Finn \& Nielson 1971, Mittal \& Munshi 1974, Anderson \& Roberts 1975 , Phromsuthirak 1977). The abnormal abundance of neutrophils in all types of papillomas and lymphocytes in plaques indicates inflammation and cellular immunity may affect papilloma persistence. The abundance of lymphocytes in plaques and their relative infrequency in lip or body papillomas however fail to directly correlate with their observed frequencies of regression, $79 \%$ in plaques and 22 and $64 \%$ in lip and body papillomas (Smith \& Zajdlik 1987) but the abundance of neutrophils in all lesions correlates with the ability of all types to regress.

The absence of observable viral particles in 19 samples of lip, focal and diffuse papillomas and 17 lip papillomas (homogenized) does not preclude a viral etiology. Epidermal papillomas in many species often contain intra- or extra-cellular viral particles (Pilcher \& Fryer 1980, Kelly et al. 1983, Yamamoto et al. 1983, 1985, McAllister et al. 1985, Bloch et al. 1986). Papillomas of white suckers have been reported to contain C-type virus particles and reserve-transcriptase (Sonstegard 1977), and that papillomas develop on white suckers kept in the laboratory (Smith \& Zajdlik 1987) further suggests that viruses are possible etiologic agents for these tumors. While not directly correlated with reported regression tendencies inflammation, cellmediated immunity and abnormal cell-cell communication identified in these papillomas likely play a role in their persistence and morphology.

Acknowledgements. Financial support was provided by the Ontario Ministry of the Environment and Environment Canada's World Wildlife Fund. Aid provided by Dr B. D. Hicks, T. Eaton and F. Keen is gratefully acknowledged.

\section{LITERATURE CITED}

Anderson, C. D., Roberts, R. J. (1975). A comparison of the effects of temperature on wound healing in a tropical and a temperate teleost. J. Fish Biol. 7: 173-182

Asashima, M., Komazaki, S., Satou, C., Oinuma, T (1982). Seasonal and geographical changes of spontaneous skin papillomas in the Japanese newt Cynops pyrrhogaster. Cancer Res. 42: 3741-3746

Asashima, M., Oinuma, T., Matsuyama. H. Nagano, M. (1985). Effects of temperature on papilloma growth in the newt, Cynops pyrhogaster. Cancer Res. 45: 1198-1205

Barber, D. L., Westermann, J. E. M. (1975). Morphological and histochemical studies on a PAS-positive granular leukocyte in blood and connective tissues of Catostomus commersoni. Am. J. Anat. 142: 205-220

Baumann, P. C., Smith, W. D., Ribick, M. (1982). Hepatic tumour rates and polynuclear aromatic hydrocarbon levels in two populations of brown bullhead. In: Cooke, M. W., et al. (eds.) Polynuclear Aromatic Hydrocarbons: 6th Int. Symp. on Physical and Biological Chemistry. Battelle Press, Columbus, p. 93-102

Black, J. J. (1982). Epidermal hyperplasia and neoplasia in brown bullheads in response to repeated applications of a Polyaromatic Hydrocarbon containing extract of polluted river sediment. In: Cooke, M. W., et al. (eds.) Polyaromatic Hydrocarbons: 6th International Symposium on Formation, Metabolism and Measurement. Battelle Press, Columbus, p. 99-111

Black, J. J. (1984). Aquatic animal neoplasia as an indicator for carcinogenic hazards to man. In: Saxena, J. (ed.) Hazard assessment of chemicals, Vol. 3. Academic Press, New York, p. 181-232

Bloch, B., Mellergaard, S., Nielson, E. (1986). Adenovirus-like particles associated with epithelial hyperplasia in dab. Limanda limanda. J. Fish Dis. 9: 281-285

Bylund, G., Valtonen, E. T., Niemela, E. (1980). Observations of epidermal papillomata in wild and cultured Atlantic salmon, Salmo salar, in Finland. J. Fish Dis. 3: 525-528

Carlisle, J. C. (1977). An epidermal papilloma of the Atlantic salmon II: Ultrastructure and etiology. J. Wildl. Dis. 13: 235-239

Carlisle, J. C., Roberts, R. J. (1977). An epidermal papilloma of 
the Atlantic salmon. 1: Epizootiology, pathology and immunology. J. Wildl. Dis. 13: 230-234

Cleland, G. B., Sonstegard, R. A. (1987). Natural killer cell activity in rainbow trout (Salmo gairdneri): effect of dietary exposure to Aroclor 1254 and/or Mirex. Can. J. Fish. Aquat. Sci. 44: 636-638

Evans, D. L., Carlson, R. L., Graves, S. S., Hogan, K. T (1984). Non-specific cytotoxic cells in fish (Ictalurus punctatus) IV Target cell binding and recycling capacity. Dev. Comp Immunol. 8: 823-833

Ferguson, H.W. (1976). The ultrastructure of plaice (Pleuronectes platessa) leucocytes. J. Fish. Biol. 8: 67-78

Finn, J. P., Nielson, N. O. (1971). The inflammatory response of raimbow trout. J. Fish. Biol. 3: 463-478

Ghadially, F. N. (1985). Ultrastructural pathology of the cell and matrix. In: A text and atlas of physiology and pathological alterations in the fine structure of cellular and extracellular components, 2nd edn. Butterworths, London, p. 798-813

Henderson, D. W. Papadimitriou, J. M. (1982). Ultrastructural appearances of tumours. A diagnostic atlas. Churchill Livingstone, London, p. 59-67

Jenson, N. J., Bloch, B (1980). Adenovirus-like particles associated with epidermal hyperplasia in cod. Nord. Veterinaermed 32: 173-175

Kelly, R. K., Nielson, O., Mitchell, S. C., Yamamoto, T (1983). Characterization of Herpesvirus vitreum isolated from hyperplastic epidermal tissue of walleye. J. Fish Dis. 6: $249-260$

Kimura, T., Yoshimizu, M., Tanaka, M. (1981). Studies on a new virus (OMV) from Oncorhynchus masou II: oncogenic nature. Fish Path. 15: 149-153

Kranz, H., Peters, N., Bresching, G., Stich, H. F. (1980). On cell kinetics in skin tumours of Pacific English sole Parophrys vetulus Girard. J. Fish Dis. 3: 125-132

Lester, R. J. G., Daniels, B. A. (1976). The eosinophilic cell of the white sucker, Catostomus commersoni. J. Fish. Res. Bd Can. 33: 139-144

Lobb, C. J. (1987). Secretory immunity induced in catfish, Ictalurus punctatus, following bath immunization. Dev. Comp. Immunol. 11: 727-738

Malins, D. C., Krahn, M. M., Brown, D. W., Rhodes, L. D., Myers, M. S., McCain, B. B., Chan, S. (1985). Toxic chemicals in marine sediment and biota from Mukilteo, Washington: relationship with hepatic neoplasms and other hepatic lesions in English Sole (Parophrys vetulus). J. natl Cancer Inst. 74: 487-495

McAllister, P. E., Lidgerding, B. C., Herman, R. L., Hoyer, L. C., Hankins, J. (1985). Viral diseases of fish: first report of carp pox in Golden ide (Leuciscus idus) in North America. J. Wildl. Dis. 21: 199-204

Mittal, A. K., Munshi, J. D. S. (1974). On the regeneration and repair of superficial wounds in the skin of Rita rita. Acta anat. 88: $424-442$

Moody, C. E., Serreze, D. V., Reno, P. W. (1985). Non-specific cytotoxic activity of teleost leukocytes. Dev. Comp. Immunol. 9: 51-64

Parish, N., Wrathmell, A., Hart, S., Harris, J. E. (1986). The leucocytes of the elasmobranch Scyliorhinus canicula L. a morphological study. J. Fish Biol. 28: 545-561

Peleteiro, M. C., Richards, R. H. (1985). Identification of lymphocytes in the epidermis of the rainbow trout, Salmo gairdneri Richardson. J. Fish Dis. 8: 161-172

Peters, G., Peters, N. (1977). Temperature-dependent growth and regression of epidermal tumors in the European eel (Anguilla anguilla L.). Ann. N.Y Acad. Sci. 298: 245-260

Peters, G, Peters, N. (1979). The influence of salinity on growth and structure of epidermal papillomas of the European eel Anguilla anguilla L. J. Fish Dis. 2: 13-26

Pfeiffer, C. J., Nagai, T., Fujimura, M., Tobe, T (1979). Spontaneous regressive epitheliomas in the Japanese newt Cynops pyrrhogaster. Cancer Res. 39: 1904-1910

Pilcher, K. S., Fryer, J. L. (1980). The viral diseases of fish: a review through 1978. Part 2: Diseases in which a viral etiology is suspected but unproven. CRC Crit. Rev. Microbiol 8: $1-25$

Phromsuthirak, P. (1977). Electron microscopy of wound healing in the skin of Gasterosteus aculeatus. J. Fish. Biol. 11: 193-206

Roberts, R. J., Young, H., Milne, J. A. (1971). Studies on the skin of plaice (Pleuronectes platessa L.) 1. The structure and ultrastructure of normal plaice skin. J. Fish Biol, 4: $87-98$

Roberts, R. J. (1978). Fish pathology. Bailliere Tindall, London, p. 29

Roberts, R. J., Bullock, A. M. (1979). Papillomatosis in marine cultured rainbow trout Salmo gairdneri. J. Fish Dis. 2 $75-77$

Roubal, F. R. (1986). Blood and other possible inflammatory cells in the sparid Acanthopagrus australis (Gunther) J. Fish. Biol. 28: 573-593

Smith, C. E., Peck, T. H., Klauds, R. J., McLaren, J. B. (1979) Hepatomas in Atlantic tomcod collected in the Hudson River estuary in New York. J. Fish Dis. 2: 313-319

Smith, I. R., Ferguson, H. W. (1985). The assessment of a point source discharge of suspected mutagenic and carcinogenic contaminants: an epidemiological approach. Proc. Ministry of the Environment Tech. Trans. Conf. \#6: 285-332

Smith, I. R., Ferguson, H. W., Hayes, M. A. (in press). Epidermal papillomas epidemic in brown bullhead, Ictalurus nebulosus, and white sucker, Catostomus commersoni, populations from Ontario, Canada. J. Fish Dis.

Smith, I. R., Zajdlik, B. A. (1987). Regression and development of epidermal papillomas affecting white suckers (Catostomus commersoni), from Lake Ontario, Canada. J. Fish Dis. 10: $487-494$

Sonstegard, R. A. (1977). Environmental carcinogenesis studies in fishes of the Great Lakes of North America. Ann. N.Y. Acad. Sci. 298: 261-269

St. Louis-Cormeir, E. A., Osterlan, C. K., Anderson, P. D. (1984). Evidence for a cutaneous secretory immune system in rainbow trout (Salmo gairdneri). Dev. Comp. Immunol. 8: $71-80$

Walczak, B. Z. (1985). Immune capability of fish - a review. Can. Tech. Rep. Fish. aquat. Sci. 1334, 33

Winqvist, G., Ljungberg, O., Hellstroem, B. (1968). Skin tumors of Northern pike (Esox lucius) II. Viral particles in epidermal proliferations. Bull. off. Int. Epiz. 69: 1023-1031

Yamamoto, T., Kelly, R. K., Nielsen, O. (1983). Epidermal hyperplasias of Northern pike (Esox lucius) associated with herpesvirus and C-type particles. Arch. Virol. 79: $255-272$

Yamamoto, T., Kelly, R. K., Nielsen, O. (1985). Epidermal hyperplasia of walleye, Stizosteion vitreum, associated with retrovirus-like type-C particles: prevalence, histologic and electron microscopic observations. J. Fish Dis. 19: $425-436$ 